\title{
Paus Fransiskus Merangkul Liyan
}

\author{
Aluisius Dian Permana ${ }^{\text {a,1 }}$ \\ Program Magister Teologi Universitas Sanata Dharma, Yogyakarta a \\ dianpermanasj@gmail.com ${ }^{1}$
}

Keywords:

migrasi,

Paus Fransiskus,

Evangelii Gaudium, hospitalitas, martabat

\begin{abstract}
Human migration or displacement has become a never ending problems for some countries. Many people had fled from their home countries to find protection from war, oppression, and persecution. The humanitarian crisis raised from migration has become the attention of Pope Francis. Pope Francis is concerned because many people do not get protection or attention from destination countries and the world. In fact, many people died or did not get proper places. The accident that took place on the Lampedusa Coast tore the hearts of Pope Francis to call on the Church and countries not to stop paying attention to the problems migration. This paper discusses the contribution of Pope Francis's thoughts on migration. Pope Francis focused more human values and human dignity. In Evangelii Gaudium, Pope Francis discusses the social dimension of evangelism. The joy of the gospel should always be preached to all people especially those who are weak, poor, and excluded. The contribution of Pope Francis' thought triggers us all to reflect on who our neighbors are and how we should behave towards our fellow human beings.
\end{abstract}

\section{PENGANTAR}

Pada tanggal 3 Oktober 2013, ada sebuah peristiwa yang memilukan dunia. Sebuah kapal yang berlayar dari Libya ke Italia terbakar dan terbalik di Pantai Lampedusa, Sisilia. Kapal tersebut membawa para migran yang terdiri dari anak-anak, perempuan, dan pria dengan jumlah penumpang sekitar 500 orang. Akibat dari peristiwa ini adalah lebih dari tiga ratus orang meninggal. Semenjak tragedi tersebut, Lampedusa menjadi tempat yang menyita perhatian. Lampedusa merupakan sebuah pulau kecil yang terletak di antara Sisilia dan Tunisia, yang terletak di Laut Mediterania. Luasnya hanya sekitar 25 kilometer persegi dan ditinggali sekitar 6.000 jiwa. Untuk mengontrol aliran migran dan mencegah masuknya mereka ke daratan Italia, Lampedusa telah menjadi pangkalan penting bagi penjaga pantai Italia dan sekarang diawasi oleh polisi dan militer. ${ }^{1}$

1 Bdk. Susanna Snyder, Joshua Ralston, and Agnes M. Brazal. Church in an Age of Global Migration (New York: Palgrave Macmillan, 2016), 29-31. 
Peristiwa serupa terjadi pada tanggal 19 April 2015. Peristiwa tersebut adalah sebuah kapal yang membawa lebih dari 800 migran tenggelam di Laut Mediterania. ${ }^{2}$ Dari data yang diperoleh, hanya 28 orang yang selamat. $^{3}$ Di Indonesia ada banyak peristiwa yang menunjukkan bahwa para migran belum sepenuhnya mendapat perlindungan. ${ }^{4}$ Tiga kasus terakhir yang mendapat perhatian adalah pada tanggal 11 Februari 2018, Adelina Sau, pekerja migran Indonesia di Malaysia, meninggal karena disiksa oleh majikannya; pada tanggal 13 Maret 2018 Santi Restauli Simbolon, pekerja migran Indonesia asal Sumatra Utara yang bekerja di Penang ditemukan tewas di dalam lemari pakaian; pada tanggal 18 Maret 2018, Muhammad Zaini Misrin, pekeja migran Indonesia asal Jawa Timur dieksekusi mati oleh otoritas Arab Saudi. ${ }^{5}$ Berbagai peristiwa tersebut merupakan beberapa contoh tentang nasib pedih yang dialami oleh para migran.

Dalam tulisan ini, penulis akan lebih membahas tentang sumbangan pemikiran Paus Fransiskus tentang migrasi. Dalam bagian selanjutnya, penulis akan menjelaskan tentang perkembangan migrasi, keprihatinan Paus Fransiskus, pengalaman hidup Paus Fransiskus berkaitan dengan migrasi, pandangan dokumen Evangelii Gaudium, maupun harapan-harapan Paus Fransiskus tentang permasalahan migrasi. Penulis juga akan membahas sedikit panjang tentang Evangelii Gaudium karena dokumen tersebut merupakan Surat Apostolik pertama Paus Fransiskus. Oleh karena itu, penulis tidak akan banyak membahas tentang perdebatan-perdebatan yang muncul mengenai migrasi. Hal ini juga disebabkan karena ada

\footnotetext{
Snyder, dkk, Church in Age, 29.

Snyder, dkk, Church in Age, 29.

Kris Razianto Mada, "Layanan Optimal untuk Penyumbang Miliaran Dollar AS", Kompas tanggal 24 Maret 2018, 8.

Mada, "Layanan Optimal", 9
}

banyak perdebatan yang begitu kompleks tentang permasalahan migrasi, entah itu masalah politik, keamananan negara, sosial, budaya, hak asasi, maupun ekonomi.

\section{PERKEMBANGAN MIGRASI}

Dalam sejarah manusia, migrasi telah menjadi bagian kehidupan dan seakan-akan tidak bisa dipisahkan dari manusia. Akan tetapi, migrasi semakin menjadi permasalahan pokok karena pengaruh globalisasi. Sekitar 200 juta orang tinggal jauh dari negara aslinya. Dari jumlah tersebut, 30 sampai 40 juta orang tidak terdaftar dan 10 juta adalah pengungsi. Permasalahan ini seringkali berbenturan dengan budaya, agama, ekonomi, keamanan nasional, hak asasi manusia, hukum, dan wacana politik lainnya. Hal ini semakin diperparah ketika ketidakadilan banyak terjadi di berbagai aspek. Dapat dikatakan bahwa migrasi mempengaruhi seluruh aspek kehidupan manusia sehingga seringkali migrasi dianggap salah satu masalah kompleks di dunia. ${ }^{6}$

Dalam sejarah migrasi di Eropa, migrasi mulai meningkat pada awal abad ke-19 dan setelah kolonial Eropa mulai runtuh. Penjajahan memiliki dampak yang sangat signifikan bagi arus migrasi, misalnya orang India dan Pakistan pindah ke Inggris, orang Vietnam, Kamboja, Aljazair, Tunisia, Maroko, dan Afrika pindak ke Prancis. Dalam hal ini, budaya dan agama seringkali menjadi sorotan. Ketika orang-orang pindah ke negara lain, ada yang meninggalkan budaya daerah asalnya, lalu mengadopsi budaya yang baru di negara yang baru. Akan tetapi, ada juga yang berusaha untuk mempertahankan budaya, bahasa, dan kebangsaannya. Dalam

6 Daniel G. Groody, "Crossing the Divide: Foundations of a Theology of Migration and Refugees", Theological Studies, Vol. 70 (2009), 638-640. 
hal agama, agama menjadi sumber spiritual bagi mereka untuk mengatasi dampak psikologis. Oleh karena itu, banyak orang yang berusaha mempertahankan agama mereka. ${ }^{7}$

Menurut data laporan migrasi internasional PBB, disebutkan bahwa jumlah orang yang tinggal di luar negara asal mereka meningkat dari 120 juta pada tahun 1990 menjadi lebih dari 191 juta pada tahun 2005. Di seluruh dunia, para migran (per 2005) menyumbang sekitar 2,9\% dari populasi dunia. Pada tahun 2005, datanya adalah Eropa 34\%, Amerika Utara 23\%, Asia 28\%, Afrika 9\%, Amerika Latin 3\% dan Ocenia 3\%. Dari jumlah tersebut, jumlah migran perempuan lebih besar daripada laki-laki, yaitu sebesar 48,6\%. Sayangnya, para perempuan seringkali mendapat perlakuan yang lebih buruk daripada laki-laki, misalnya di Asia Tengah (terutama Uzbekistan), ada lebih dari 10.000 perempuan yang dijadikan budak seks oleh para sindikat kejahatan. Risiko yang paling berbahaya dari migrasi adalah perdagangan manusia atau human trafficking. Manusia diperjualbelikan seperti barang dagangan. Tak dapat dipungkiri bahwa migrasi tak jarang membawa dampak negatif bagi ekonomi, psikologis, lapangan pekerjaan, dsb. ${ }^{8}$

\section{DUKA PARA MIGRAN, DUKA PAUS FRANSISKUS}

Sejak Konsili Vatikan II, teologi disusun kembali dalam berbagai cara sebagai tanggapan terhadap tantangan dunia modern, seperti gerakan pembebasan, feminisme, pluralisme agama, keragaman budaya, dan estetika. ${ }^{9}$ Dokumen Gereja yang membahas

7 Gemma Tulud Cruz, "Between Identitty and Security: Theological Implications of Migration in the Context of Globalization", Theological Studies, Vol. 69 (2008), 358-359.

8 Cruz, "Between Identity", 360-365.

9 Groody, "Crossing the Divide", 641. pertama kali tentang migrasi adalah Apostolic Constitution. Dokumen tersebut dikeluarkan oleh Paus Pius XII pada tanggal 1 Agustus 1952. Meskipun demikian, kenyataannya, masalah migrasi belum menjadi perhatian sungguh-sungguh bagi para teolog.

Perhatian terhadap para migran menguat kembali sejak terpilihnya Mario Bergoglio terpilih menjadi Paus pada tanggal 13 Maret 2013. ${ }^{10}$ Pengalaman pedih yang dialami oleh para migran menyita perhatian Paus Fransiskus. Sejak terpilih menjadi Paus, Paus Fransiskus sungguh menunjukkan kedekatannya dengan orang-orang miskin. Paus Fransiskus dikenal sebagai pribadi yang menaruh kepedulian terhadap orang-orang yang terpinggirkan. Di Buenos Aires, Paus Fransiskus sungguh perhatian terhadap kehidupan para migran di perkampungan kumuh. Sebagian besar mereka berasal dari Peru, Paraguay, Bolivia, dan Brasil. Perhatian Paus Fransiskus pun tampak melalui hal-hal yang sederhana. Paus Fransiskus selalu meminta waktu untuk bertemu dengan komunitas migran dan makan bersama dengan mereka di dapur umum. Kunjungan Paus Fransiskus ke Lampedusa merupakan salah satu bentuk perhatian dari Paus Fransiskus sungguh merangkul para migran. ${ }^{11}$

Kepedulian Paus Fransiskus terhadap para migran mendapat dukungan dari PBB. Sedikit membahas tentang beberapa perdebatan tentang migrasi, PBB memberikan ancaman sanksi kepada negara-negara Uni Eropa yang tidak mau menerima kuota yang sudah disepakati. ${ }^{12}$ Akan tetapi, anjuran Paus Fransiskus sempat mendapat kritikan dari Presiden Donald Trump, yang waktu itu masih menjadi calon, bahwa ia akan mem-

\footnotetext{
10 Yusti H. Wuar, "Suara Paus bagi Para Migran", Hidup, No. 13, 26 Maret 2017, 8.

11 Snyder, dkk, Church in Age, 30.

12 Wuar, "Suara Paus", 9.
} 
bangun dinding di sepanjang perbatasan bagian selatan AS untuk menghalangi imigran dari Meksiko. ${ }^{13}$ Selain itu, Trump bersumpah akan mengusir sekitar 11 juta migran Muslim dari AS. ${ }^{14} \mathrm{Hal}$ ini berkaitan dengan keamanan dan kedaulatan negara. Menanggapi pernyataan Donald Trump, Paus Fransiskus mengatakan bahwa seseorang yang hanya berpikir untuk membangun dinding di mana ia berada, dan tidak membangun jembatan perdamaian, ia bukanlah seorang Kristiani. ${ }^{15}$

\section{PENGALAMAN HIDUP SEBAGAI TITIK PIJAK}

Keberpihakan Paus Fransiskus kepada para migran adalah salah satu sikap yang menyita perhatian dunia. Bahkan Paus Fransiskus dinobatkan sebagai person of the year oleh majalah Time. ${ }^{16}$ Kepedulian Paus Fransiskus terhadap migran seakan-akan tidak bisa dilepaskan dari latar belakang keluarga dan pengalaman hidupnya. Dari sejarah hidupnya, hal tersebut seakan-akan tidaklah mengherankan. Ayahnya, Mario Jose Bergolio adalah imigran asal Piedmont, Italia. Ayahnya hijrah dari Italia menuju Argentina. Sementara ibunya, Regina Maria Sivori lahir di Buenos Aires, Argentina, tetapi imigran asal Italia yang mengadu nasib ke Argentina. Sepak terjang Paus Fransiskus dalam melindungi para imigran acapkali dikaitkan dengan aktualisasi teologi pembebasan corak Amerika Latin di Argentina. ${ }^{17}$

Dalam pengalaman hidupnya, sebelum terpilih menjadi Paus, Paus Fransiskus selalu berusaha peduli terhadap masalah aktu- al dan kemiskinan. Saat menjadi Provinsial Serikat Yesus Argentina pada tahun 1973, ia menekankan agar Serikat Yesus menaruh perhatian terhadap masalah-masalah sosial. Hal yang menarik adalah ada empat aspek yang selalu menonjol selama ia menjadi seorang Imam, yaitu ia sangat menekankan pelayanan kepada orang miskin; ia memiliki devosi dan iman yang teguh; ia memiliki visi misioner untuk gereja; ia menolak segala bentuk klerikalisme. Ternyata, benih-benih yang baik dalam ada dalam diri Paus Fransiskus sudah ada sejak ia menjadi seorang Jesuit. Keprihatinannya terhadap masalahmasalah sosial ini membuatnya enggan untuk tinggal dalam kemewahan dan ia lebih memilih tinggal di apartemen sederhana. ${ }^{18}$

Dalam kerasulannya, Paus Fransiskus berkali-kali menegaskan bahwa Gereja hendaknya keluar, yang terlibat dan mendukung, yang berbuah dan bersukacita. ${ }^{19}$ Bahkan Paus Fransiskus menegaskan bahwa Gereja yang terdiri dari komunitas-komunitas hendaknya mau menemani duka orang lain. Gereja terdiri dari komunitas yang terlibat dengan kata dan perbuatan dalam hidup orang sehari-hari, komunitas ini menjembatani jarak, mau menghambakan diri jika perlu, serta merangkul hidup manusia, dengan menyentuh kemanusiaan Yesus yang menderita dalam diri sesamanya. Oleh karena itu, komunitas yang mewartakan Injil siap menemani. Menemani kemanusiaan dalam seluruh prosesnya, betapa pun sulit dan lamanya. ${ }^{20}$ Paus Fransiskus menginginkan Gereja yang terjun ke dalam permasalahan dunia. ${ }^{21}$
13 Wuar "Suara Paus", 10.

14 Wuar, "Suara Paus", 10.

15 Wuar, "Suara Paus", 10.

16 Jhon L. Allen, The Francis Miracle (New York: Time Book, 2015), 4.

17 Wuar, "Suara Paus", 9.
18 Allen, The Francis, 19-25.

19 Evangelii Gaudium, art. 234.

20 Evangelii Gaudium, art. 24.

21 Howard Chua-Eoan and Elizabeth Dias, "The People Pope's", Time, December 2013, 33 


\section{SUMBANGAN PEMIKIRAN PAUS FRAN- SISKUS}

Ada beberapa visi yang dapat ditangkap dari upaya Paus Fransiskus menaruh kepedulian terhadap para migran. Pertama, Paus Fransiskus menempatkan misi Allah di tengah dunia untuk memberitakan Injil kepada siapapun. Oleh karena itu, para migran, tanpa memandang status sosial mereka, adalah umat Allah yang perlu dirangkul. Kedua, Paus Fransiskus menyerukan agar para migran mendapatkan pendampingan seacra jelas, entah itu dari Gereja maupun dari negara-negara. Kegita, para migran adalah orang-orang miskin, lemah dan tak berdaya yang perlu mendapat jaminan hidup yang lebih layak.. ${ }^{22}$ Dalam Seruan Apostolik Evangelii Gaudium, Paus Fransiskus menegaskan demikian:

\begin{abstract}
Maka marilah kita bergerak keluar, marilah kita bergerak keluar menawarkan kepada setiap orang hidup Yesus Kristus. Di sini saya mengulangi bagi seluruh Gereja apa yang telah sering saya katakan kepada para imam dan umat awam di Buenos Aires: saya lebih menyukai Gereja yang memar, terluka dan kotor karena telah keluar di jalan-jalan, daripada Gereja yang sakit karena menutup diri dan nyaman melekat pada rasa amannya sendiri. Saya tidak menginginkan Gereja yang menjadi pusat dan berakhir terperangkap dalam jerat obsesi dan prosedur. ${ }^{23}$
\end{abstract}

Dalam memperingati Hari Migran Sedunia pada tanggal 19 Januari 2014, Paus Fransiskus menegaskan bahwa para migran adalah saudara-saudari yang perlu dihormati dan disambut. Paus Fransiskus berharap bahwa negara-negara bisa menyambut me-

22 Synder, dkk, Church in Age, 35.

23 Evangelii Gaudium, art. 49. reka tanpa merendahkan budaya. ${ }^{24}$ Dalam forum Integration and Development: From Reaction to Action di Scalabrini Internasional Migration Network, Vatikan, 21-22 Februari 2017, Paus Fransiskus mengatakan bahwa para migran terkadang dianggap tidak layak karena mereka dicap pendatang, penyelundup, atau manusia baru. ${ }^{25}$ Ketidakpedulian terhadap migran seringkali terjadi karena retorika populis yang berkembang saat ini, yaitu imigran bukan bagian dari kita. ${ }^{26}$

Meskipun Paus Fransiskus bukanlah seorang teolog yang memiliki rumusan tentang teologi migrasi yang baku, tetapi visi Paus Fransiskus sangatlah jelas, bahwa semua pihak perlu terlibat dalam menangani masalah migrasi karena hal ini berkaitan dengan nilai-nilai kemanusiaan. Paus Fransiskus mengajak masyarakat untuk mengingat kembali peristiwa di Lampedusa pada tanggal 3 Oktober 2013. ${ }^{27}$ Peristiwa tersebut merupakan peristiwa yang menyedihkan dan memilukan bagi banyak orang. Paus Fransiskus berharap agar peristiwa tersebut tidak terjadi lagi.

Dalam homilinya ketika Paus Fransiskus berkunjung ke Lampedusa, Paus Fransiskus mengajak kita untuk berefleksi tentang bagaimana kepedulian kita terhadap ratusan orang yang meninggal terombang ambing lautan.

Adakah di antara kita yang menangis karena situasi ini dan menyukai peristiwa ini? Adakah di antara kita berduka atas kematian saudara-saudari kita? Apakah ada di antara kita yang menangisi para pengung-

\footnotetext{
24 Snyder, dkk, Church in Age, 33.

25 Wuar, "Suara Paus", 9.

26 Wuar, "Suara Paus", 9.

27 Sebastian Maillard, "Pope Francis, Refugees and Recovering Europe's Soul", The Way, Vol. 55, No. 4, Oktober (2016), 8081.
} 
si? Untuk ibu-ibu muda yang membawa bayi mereka? Untuk para lelaki yang berjuang demi keluarga mereka? Kita adalah masyarakat yang telah lupa bagaimana menangis, bagaimana menaruh belas kasihan terhadap 'penderitaan' orang lain: globalisasi ketidakpedulian telah mengambil belas kasih kita untuk peduli terhadap penderitaan orang lain. ${ }^{28}$

\section{EVANGELII GAUDIUM: PEWARTAAN IN- JIL BAGI YANG LEMAH}

Dalam seruan Apostolik Evangelii Gaudium yang dikeluarkan tanggal 24 November 2013, Paus Fransiskus menekankan lima hal yang dibahas. Tema-tema tersebut adalah 1) perubahan perutusan Gereja, 2) krisis komitmen bersama, 3) pewartaan Injil, 4) dimensi sosial evangelisasi, 5) para pewarta Injil yang dipenuhi roh. Dalam Seruan Apostolik tersebut, Paus Fransiskus menyatakan bahwa ia ingin Gereja memulai babak baru evangelisasi yang ditandai dengan sukacita, antusiasme, dan optimisme.

Kasih menjadi poin penting yang hendak ditekankan oleh Paus Fransiskus. Kasih meniadakan sekat-sekat tentang arti kepedulian terhadap orang lain. Hal ini bertitik tolak dari pewartaan Injil ditujukan kepada siapapun dan di manapun. Yesus merangkul siapapun terutama mereka yang lemah, miskin, dan tersingkir. Bahkan hal tersebut menjadi misi Yesus. Mengenai hal tersebut, Injil Lukas memberikan narasi yang sungguh menarik.

28 Has any one of us wept because of this situation and others like it? Has any one of us grieved for the death of these brothers and sisters? Has any one of us wept for these persons who were on the (refugee) boat? For the young mothers carrying their babies? For the men who were looking for means of supporting their families? We are a society which has forgotten how to weep, how to experience compassion "suffering with" others: the globalization of indifference has taken from us the ability to weep. (Daniel Groody,"Migrants and Refugees: Christian Faith and the Globalization of Solidarity", International Review of Mission, November 2015, 314-323).
"Ia datang ke Nazaret tempat Ia dibesarkan, dan menurut kebiasaan-Nya pada hari Sabat Ia masuk ke rumah ibadat, lalu berdiri hendak membaca dari Alkitab. Kepada-Nya diberikan kitab nabi Yesaya dan setelah dibuka-Nya, Ia menemukan nas, di mana ada tertulis:

'Roh Tuhan ada pada-Ku, oleh sebab Ia telah mengurapi Aku, untuk menyampaikan kabar baik kepada orang-orang miskin; dan Ia telah mengutus Aku untuk memberitakan pembebasan kepada orangorang tawanan, dan penglihatan bagi orang-orang buta, untuk membebaskan orang-orang tertindas, untuk memberitakan tahun rahmat Tuhan telah datang.'

Kemudian Ia menutup kitab itu, memberikannya kembali kepada pejabat, lalu duduk; dan mata semua orang dalam rumah ibadat itu tertuju kepada-Nya. Lalu Ia memulai mengajar mereka, kata-Nya: "Pada hari ini genaplah nas ini sewaktu kamu mendengarnya." Dan semua orang itu membenarkan Dia dan mereka heran akan kata-kata yang indah yang diucapkan-Nya." (Luk 4: 16-22).

Melalui Evangelii Gaudium, Paus Fransiskus kembali menggaungkan tentang arti kepedulian terhadap yang lemah, yang merupakan bagian penting dalam pewartaan Injil. Ada banyak peristiwa yang telah melukai nilai-nilai kemanusiaan. Paus Fransiskus menarasikan demikian: "Saya perlu memberi perhatian dan mendekatkan diri kepada bentuk-bentuk baru kemiskinan dan kerentanan, di mana kita dipanggil untuk mengenali Kristus yang menderita, bahkan jika hal ini tampaknya tidak memberi manfaat nyata dan langsung. Saya berpikir tentang para tunawisma, para pecandu napza, para pengungsi, penduduk asli, orang lanjut 
usia yang semakin terasing dan terlantar, dan banyak orang lainnya." ${ }^{29}$

Dari pembacaan penulis dalam dokumen Evangelii Gaudium, Paus Fransiskus tidak secara spesifik membahas tentang migran ataupun tentang pengungsi. Paus Fransiskus lebih menegaskan bahwa evangelisasi merupakan tugas Gereja kepada siapapun. Meskipun demikian, ada dua nomor yang menyoroti tentang migrasi, yaitu nomor 210 dan 253. Dalam nomor tersebut, Paus Fransiskus menaruh keprihatinan terhadap berbagai masalah migrasi dan mengajak semua lapisan masyarakat untuk menaruh kepedulian terhadap para migran. Paus Fransiskus menegaskan demikian:

Para migran memberikan tantangan khusus bagi saya, karena saya adalah imam dari seluruh Gereja tanpa perbatasan, Gereja yang menganggap dirinya ibu bagi semua. Oleh sebab itu, saya menyerukan kepada setiap negara untuk memiliki keterbukaan murah hati yang akan mampu menciptakan bentuk-bentuk sintesis budaya baru tanpa perlu takut kehilangan identitas lokal. Betapa indahnya kota-kota yang mampu mengatasi kecurigaan yang melumpuhkan, mengintegrasikan orangorang yang berbeda dan menjadikan integrasi ini suatu faktor baru dari pengembangan. ${ }^{30}$

Kita umat kristiani hendaknya menyambut dengan penuh kasih dan rasa hormat pada imigran Muslim yang masuk ke negara-negara kita seperti kita mengharapkan dan meminta untuk diterima dan dihargai di negara-negara dengan tradisi Islam. Saya minta dan dengan rendah hati saya mohon dengan sangat kepada negara-ne- gara tersebut agar memberi umat Kristiani kebebasan untuk beribadat dan merayakan iman mereka, dalam terang kebebasan yang dinikmati oleh para pengikut Islam di negara-negara Barat! ${ }^{31}$

Paus Fransiskus menekankan kepada kita semua bahwa kita harus peduli terhadap permasalahan-permasalahan kemanusiaan dan martabat manusia. Dalam berbagai kasus migrasi, tak jarang martabat manusia tidak diperhatikan dan dianggap rendah. Bahkan para migran sering dianggap orang yang harus disingkiri. Perhatian terhadap para migran merupakan bagian dari dimensi sosial evangelisasi. Paus Fransiskus menekankan bahwa kesejahteraan umum dan perdamaian dalam masyarakat perlu diusakan bersama. Untuk memajukan pembangunan suatu bangsa dalam perdamaian, keadilan dan persaudaraan ada empat prinsip yang berkaitan dengan ketegangan-ketegangan yang selalu hadir dalam setiap realitas sosial. Keempat prinsip ini berasal dari pilar-pilar ajaran sosial Gereja, yang bertindak sebagai parameter rujukan yang utama dan fundamental untuk menafsir dan menilai gejala sosial. ${ }^{32}$

Dalam pilar-pilar itu, Paus Fransiskus ingin mengajukan empat prinsip khusus yang dapat membimbing perkembangan hidup dalam masyarakat dan pembangunan bangsa di mana perbedaan-perbedaan diselaraskan dalam usaha bersama. Paus Fransiskus berbuat demikian atas dasar keyakinan bahwa penerapan keempat prinsip bisa menjadi jalan sejati menuju perdamaian di setiap bangsa dan di seluruh dunia. ${ }^{33}$ Empat pilar tersebut adalah waktu lebih besar daripada ruang, kesatuan menang atas pertentangan,
Evangelii Gaudium, art. 253

32 Evangelii Gaudium, art. 221

33 Evangelii Gaudium, art. 221 
kenyataan lebih penting daripada gagasan, keseluruhan lebih besar daripada bagian. ${ }^{34}$ Tidak mudah untuk mewujudkan empat pilar ini, tetapi Paus Fransiskus mengajak semua orang untuk optimis dan totalitas. ${ }^{35}$

Dalam pilar waktu lebih besar daripada ruang, Paus Fransiskus menjelaskan tentang ketegangan terus menerus terjadi antara kepenuhan dan keterbatasan. ${ }^{36}$ Kepenuhan membangkitkan keinginan untuk memiliki segalanya, sementara keterbatasan merupakan dinding yang dipasang di hadapan kita. ${ }^{37}$ Secara lebih detail Paus Fransiskus menguraikan demikian:

Prinsip ini memampukan kita untuk bekerja dalam jangka panjang, tanpa terobsesi dengan hasil yang segera. Prinsip ini membantu kita dengan sabar bertahan dalam situasi yang sulit dan merugikan, atau perubahan-perubahan dalam rencana-rencana kita sebagai akibat perkembangan realitas. Kita diundang untuk menerima ketegangan antara kepenuhan dan keterbatasan, dan memberikan prioritas kepada waktu. Salah satu kesalahan yang kadang-kadang kita amati dalam kegiatan sosio-politik adalah bahwa ruang dan kekuasaan lebih disukai daripada waktu dan proses. Memberikan prioritas kepada waktu berarti melibatkan diri untuk memulai proses daripada memiliki ruang. ${ }^{38}$

Dalam pilar kesatuan menang atas pertentangan, sesungguhnya, sebuah langkah-langkah kecil dapat ditempuh untuk menyelesaikan konflik dan dalam menciptakan perdamaian. ${ }^{39}$ Paus Fransiskus

\footnotetext{
34 Maillard, "Pope Francis....", 83.

35 Evangelii Gaudium, art. 237.

36 Evangelii Gaudium, art. 222.

37 Evangelii Gaudium, art. 222.

38 Evangelii Gaudium, art. 223.

39 Maillard, "Pope Francis....", 84.
}

mengutarakan bahwa konflik tidak dapat diabaikan ataupun disembunyikan. ${ }^{40} \mathrm{Ke}$ tika terjadi konflik, beberapa orang hanya melihatnya saja dan berlalu seolah-olah tidak ada sesuatu pun yang terjadi; mereka cuci tangan atas hal itu dan melanjutkan kehidupan mereka. Namun, ada juga orang yang tergerak hatinya untuk menangani pertentangan. ${ }^{41}$ Paus Fransiskus memberikan penekanan demikian:

Pesan perdamaian bukan tentang damai hasil tawar-menawar, melainkan lebih merupakan keyakinan bahwa kesatuan yang dibawa oleh Roh dapat menyelaraskan setiap keragaman. Perdamaian itu mengatasi setiap konflik dengan menciptakan sebuah sintesis baru dan menjanjikan. Keragaman itu indah bilamana senantiasa rela masuk ke dalam proses rekonsiliasi dan memeteraikan semacam perjanjian budaya yang menghasilkan keragaman yang diperdamaikan. ${ }^{42}$

Dalam pilar kenyataan lebih penting daripada gagasan, Paus Fransiskus menekankan tentang kesinambungan antara gagasan dan kenyataan. ${ }^{43}$ Penjelasan ini berkaitan dengan sabda Allah dan pelaksanaannya dalam praktik. ${ }^{44}$ Paus Fransiskus menegaskan demikian:

Hal ini membantu kita untuk melihat bahwa sejarah Gereja adalah sejarah keselamatan, untuk mengingat para kudus yang telah menginkulturasikan Injil ke dalam kehidupan bangsa-bangsa kita dan untuk memetik buah kaya tradisi Gereja selama dua ribu tahun, tanpa pretensi dapat mengembangkan pemikiran yang terlepas

\footnotetext{
40 Evangelii Gaudium, art. 226

41 Evangelii Gaudium, art. 227.

42 Evangelii Gaudium, art. 227.

43 Evangelii Gaudium, art. 232.

44 Evangelii Gaudium, art. 233.
} 
dari kekayaan tradisi ini, seolah-olah kita ingin menjadi penemu Injil. Pada saat yang sama, prinsip ini memaksa kita untuk mempraktikkan sabda, untuk melakukan karya-karya keadilan dan cinta kasih yang membuat sabda itu berbuah. ${ }^{45}$

Dalam pilar keseluruhan lebih besar daripada bagian, Paus Fransiskus mengajak masyarakat untuk memperhatikan dimensi global tanpa mengesampingkan yang lokal. ${ }^{46}$ Jika tidak ada kesinambungan akan mengakibatkan dua hal, yaitu pertama, orang terjebak dalam universalisme yang abstrak dan mengglobal, yang hanya mengikuti langkah orang lain; kedua, orang terpisah dari dunia dan tidak mampu menghadapi tantangan-tantangan dunia. ${ }^{47}$ Paus Fransiskus menguraikan demikian:

Bagi kita umat Kristiani, prinsip ini juga berbicara tentang totalitas atau integritas Injil yang diwariskan Gereja kepada kita dan mengutus kita untuk mewartakannya. Kekayaan yang penuh merangkul orangorang terpelajar dan pekerja, pengusaha dan seniman, singkat kata, semua orang. Injil memiliki prinsip totalitas yang intrinsik: Injil tidak akan berhenti menjadi Kabar Baik selama belum diwartakan kepada semua orang, selama belum menyembuhkan dan menguatkan setiap aspek kemanusiaan, selama belum menyatukan semua manusia di meja perjamuan Kerajaan Allah. Keseluruhan lebih besar daripada bagian. ${ }^{48}$

\section{HOSPITALITAS: MERANGKUL LIYAN (ORANG LAIN)}

Tak dapat dipungkiri bahwa hidup doa menjadi dasar bagi karya Paus Fransiskus. ${ }^{49}$ Kedekatan relasi dengan Kristus menjadi kekuatan baginya dalam merasul. ${ }^{50}$ Dalam Seruan Apostolik Evangelii Gaudium, Paus Fransiskus menegaskan bahwa apa yang penting di atas segalanya adalah iman yang bekerja oleh kasih (Gal 5:6). Pekerjaan kasih yang ditujukan kepada sesama adalah ungkapan lahiriah yang paling sempurna dari rahmat batin Roh, yaitu dasar hukum baru terletak dalam rahmat Roh Kudus, yang diwujudnyatakan dalam iman yang bekerja melalui kasih. ${ }^{51}$ Dalam buku yang berjudul On Heaven and Earth, Paus Fransiskus menjelaskan doa demikian:

Doa adalah tindakan, tetapi terkadang sebagai kontrol terhadap diri, bahkan terkadang ada keinginan untuk mengendalikan Tuhan. Dalam doa, ada saat untuk hening, adorasi, ataupun menunggu untuk menyaksikan apa yang terjadi. Dalam doa, ada keheningan dan tawar menawar dengan Tuhan. Hal ini seperti peristiwa ketika Abaraham dengan Tuhan melakukan negosiasi terkait warga Sodom dan Gomora yang dilecehkan. Musa juga sempat tawar menawar dengan Tuhan agar Tuhan tidak menghukum bangsanya. Dalam doa tersirat kerendahan hati dan memuliakan Tuhan. $^{52}$ 
Bercermin pada pengalaman Yesus yang menjumpai setiap orang tanpa kecuali, secara khusus kepada orang yang miskin (Luk 14: 14), Paus Fransiskus menegaskan bahwa kita dipanggil untuk menemukan Kristus di dalam diri mereka, untuk meminjamkan suara kita bagi perkara-perkara mereka, tetapi juga menjadi sahabat-sahabat mereka, mendengarkan mereka, memahami mereka dan menerima hikmat tersembunyi yang ingin disampaikan Allah kepada kita melalui mereka. ${ }^{53}$ Oleh karena itu, perhatian kita harus ditujukan kepada orang-orang miskin. ${ }^{54}$ Hospitalitas lebih mengarah tentang bagaimana Paus Fransiskus bermaksud merangkul semua orang terlebih orang-orang yang terpinggirkan.

Paus Fransiskus tiada henti mengingkatkan kepada kita semua untuk peduli terhadap para migran. Dalam memperingati hari Perdamaian yang ke-51 pada bulan Januari 2018, Paus Fransiskus senantiasa mengajak setiap orang untuk peduli terhadap kaum migran. Ada empat hal yang ditekankan oleh Paus Fransiskus, yaitu welcoming, protecting, promoting, dan integrating. Melalui empat hal tersebut, Paus Fransiskus mengajak setiap orang untuk menaruh respek terhadap martabat orang lain. Berikut ini adalah penjelasannya: ${ }^{55}$

Pertama, welcoming, yaitu panggilan untuk menerima atau menyambut para migran menuju negara-negara tertentu akibat penganiayaan dan kekerasan di negaranya. Kitab Suci mengingatkan kita untuk jangan lupa menunjukkan keramahan kepada orang

53 Evangelii Gaudium, art. 198.

54 Evangelii Gaudium, art. 48.

55 Penjelasan ini saya sarikan dari Pesan Paus Fransiskus pada hari Perdamaian Dunia pada tanggal 1 Januari 2018. (Pope Francis, "Message of Hollines Pope Francis for the Celebration of the 51 st World Day of Peace", http://w2.vatican.va/content/francesco/en/messages/peace/documents/papa-francesco_20171113_messaggio-51 giornatamondiale-pace2018. html,_diakses pada tanggal 15 Maret 2020) asing, sebab dengan berbuat demikian beberapa orang dengan tidak diketahuinya telah menjamu malaikat-malaikat (Ibrani 13: 2). Kedua, protecting, yaitu melindungi dan membela martabat manusia yang mencari suaka dan keamanan. Hal ini untuk mencegah segala bentuk eksploitasi. Tuhan sendiri memberikan contoh bahwa Ia mengawasi orang asing dan memelihara anak yatim dan janda (Mzm 146:9).

Ketiga, promoting, yaitu perlu adanya dukungan terhadap penanganan para migran. Paus Fransiskus lebih menganjurkan pembekalan pendidikan kepada anak-anak dan kaum muda agar kelak mereka dapat menjalin dialog. Kitab Suci mengajarkan bahwa Allah mengasihi orang asing, memberi makanan dan pakaian dan kita harus mencintai orang asing karena kita pun dahulu adalah orang asing di Mesir (Ul. 10: 18-19). Keempat, integrating, yaitu mengajak para migran untuk berpartisipasi dalam kehidupan masyarakat sehingga mereka merasa diterima. Partisipasi ini dalam memupuk kerja sama dan pelayanan yang lebih maksimal. Santo Paulus menyatakan bahwa kamu bukan lagi orang asing dan pendatang, tetapi kawan sewarga dari anggota-anggota keluarga Allah (Efesus 2: 19).

Pengalaman sebelum menjadi Paus telah membentuk Paus Fransiskus menjadi seorang imam yang peduli terhadap masalahmasalah sosial. Beberapa pengalaman tersebut adalah perjumpaannya dengan para migran yang ada di Argentina. Paus Fransiskus mengalami situasi Gereja sebelum Konsili Vatikan II. ${ }^{56}$ Pengalaman tersebut terus membuatnya peduli dan peka terhadap masalah-masalah sosial. Keputusannya untuk sungguh menaruh perhatian terhadap para

\footnotetext{
56 Philip Endean, "Writing on Jesuit Spirituality by Jorge Mario Bergoglio", Studies In the Spirituality of Jesuit, 45/3, Autumn 2013, 4.
} 
migran tentunya berdasarkan keputusan yang matang bahwa Paus Fransiskus ingin menjunjung nilai-nilai kemanusiaan.

Bagi Paus Fransiskus, setiap orang harus cermat terhadap masalah-masalah yang terjadi di dunia. Kepedulian terhadap masalah sosial selalu mengingatkan kita akan belas kasih Allah kepada manusia kendati manusia berdosa. Dalam pengalaman Paus Fransiskus, membangun kepedulian terhadap para migran tidaklah mudah, tetapi para migran adalah orang-orang yang layak mendapat perhatian karena mereka adalah orang-orang menderita, terasing dan sama-sama ciptaan Tuhan. Dalam hal ini Paus Fransikus mengambil perikop Matius 4: 2427. Paus Fransiskus hendak menegaskan bahwa setiap orang dipanggil untuk berjuang di kebun anggur-Nya termasuk terlibat dalam menangangi para migran. Yesus sendiri telah memberi contoh bahwa Ia sungguh menaruh kepedulian terhadap orang miskin dan terasing. Bahkan Yesus merangkul orang-orang berdosa dan tersisihkan dalam masyarakat.

\section{PARA MIGRAN ADALAH SESAMA KITA}

Preferential option for (and with) the poor adalah komitmen dan tanggung jawab kita bersama. Para migran merupakan orang-orang yang rentan karena seringkali hak-hak mereka sebagai manusia dirampas. Mereka sering ditolak oleh negara-negara, menjadi korban perdagangan manusia, hidup terkatung-katung di tengah lautan, kurang mendapat perhatian dari negara, dan tidak sedikit orang yang meninggal karena kelaparan. Sikap Paus Fransiskus terhadap para migran menjadi teladan sekaligus ajakan agar setiap negara berani bertindak secara konkret tentang masalah migrasi. Gaudium et Spes menegaskan bahwa jalan cinta kasih terbuka bagi semua orang, dan bahwa usaha untuk membangun persaudaraan universal tidak akan percuma. Sekaligus, Tuhan mengingkatkan bahwa cinta kasih itu jangan hanya dikejar dalam hal-hal besar, melainkan pertama-pertama dalam situasi hidup yang serba bisa. ${ }^{57}$

Di Indonesia, ada beberapa lembaga kemanusiaan yang menaruh perhatian terhadap para migran, salah satunya Jesuit Refugee Service (JRS) ${ }^{58}$ yang berusaha untuk terlibat dalam menangani pengungsi. Hadirnya JRS sebagai salah satu usaha Serikat Yesus dalam mendampingi para pengungsi. Berdasarkan rumusan Konvensi PBB 1951 tentang status pengungsi (UN Convention 1951 Relating to Status of Refugee), pengungsi diartikan orang yang karena ketakutan yang sangat beralasan untuk dianiaya karena alasan ras, agama, kebangsaan, keanggotan dalam kelompok sosial tertentu atau pendapat politik berada di luar negeri kelahirannya tidak dapat atau karena ketakutan itu tidak bersedia memanfaatkan perlindungan negaranya.

JRS Indonesia mulai dibentuk pada tahun 1999. Latar belakangnya adalah konflik di Timor Leste sebagai akibat dari Timor Leste yang ingin merdeka. Kemudian, pada tahun 2000-2004, JRS Indonesia berusaha terlibat menangani kebutuhan para pengungsi di Aceh dan Maluku karena konflik di wilayah tersebut. JRS menjadi wujud nyata kepedulian Serikat Yesus terhadap masalah konflik dan pengungsi. Tentu, hadirnya JRS tidak bermaksud menyombongkan karya Serikat Yesus. Akan tetapi, JRS menegaskan kembali bahwa kita semua diajak untuk terlibat dalam merangkul orangorang yang tersisihkan dan menderita.

57 Gaudium et Spes, art. 38.

58 Jesuit Refugee Service digagas oleh Pedro Arrupe, SJ pada tahun 1980 sewaktu ia menjadi Jenderal Serikat Yesus pada tahun 1965 - 1990 . 
Bagi Paus Fransiskus, Gereja hendaknya memberikan contoh dalam merangkul orang-orang yang menderita. Oleh karena itu, dalam bagian selanjutnya, penulis akan sedikit menjelaskan tentang pelayanan Gereja. Franz Magnis-Suseno, dalam buku Katolik Itu Apa? Sosok, Ajaran, Kesaksiannya, berpendapat bahwa pelayanan Gereja hendaknya tanpa batas karena Allah dalam kasih-Nya menawarkan keselamatan kepada semua orang, apa pun kepercayaan mereka. ${ }^{59}$ Dengan demikian, pelayanan Gereja tidak hanya berbentuk sakramen-sakramen saja, tetapi juga bidang-bidang lainnya.

Gereja tidak dapat membatasi diri pada gedung gereja, ibadat, dan doa-doa - betapa pun perayaan Ekaristi, pemberian sakramen, dan doa bersama tetap merupakan sumber rahmat yang memberikan kekuatan kepadanya. Akan tetapi, Gereja sekarang harus melibatkan diri agar mereka yang sudah putus asa dapat merasakan bahwa Allah tidak meninggalkan mereka. Seperti misalnya dalam Jesuit Refugee Service di mana para sukarelawan membantu kaum pengungsi di seluruh dunia. Karena itu Paus Yohanes Paulus II dan Paus Fransiskus pergi ke Asisi untuk berdoa bersama dengan tokoh-tokoh agama-agama lain. Kebersamaan dengan saudara-saudari Kristen lain dan dengan agama-agama dunia menjadi amat penting dalam Gereja untuk menjalankan panggilannya. Membangun hubungan saling percaya dan bekerja sama demi kebaikan di dunia dengan agama-agama lain merupakan tuntutan zaman ini bagi Gereja. Meski sadar bahwa ia sendiri terdiri atas manusia-manusia pendosa, Gereja mengetahui diri diutus untuk membuat nyata kekuasaan kasih, kerahiman, penyembuhan, dan rekonsiliasi yang ditawarkan Allah. ${ }^{60}$

59 Franz Magnis-Suseno, Katolik Itu Apa? Sosok, Ajaran, Kesaksian (Yogyakarta: Penerbit Kanisius, 2017), 190.

60 Magnis-Suseno, Katolik Itu Apa?, 190.
Sebetulnya, Gereja Katolik termasuk Gereja Katolik di Indonesia, dikenal dengan karya-karya karitatifnya, entah lewat bantuan-bantuannya terhadap orang miskin maupun lewat yayasan-yayasannya. ${ }^{61}$ Meskipun demikian, Gereja tetap membutuhkan lembaga-lembaga bantuan yang memberi perlindungan kepada yang tidak berdaya dan tidak bersuara, sebagai misal pendampingan buruh, pendampingan transmigran, perlindungan terhadap penduduk asli, dsb. ${ }^{62}$

Menurut Paus Benediktus, pelayanan amal kasih Gereja memiliki kekhasan dibandingkan dengan pelayanan amal kasih pada umumnya. Pertama, bagi semua yang aktif dalam organisasi karitatif Gereja, haruslah menjadi ciri khas, bahwa mereka tak hanya melakukan dengan tepat apa yang harus dilakukan, melainkan melayani orang lain itu dengan hati, sehingga orang itu merasakan kebaikan manusiawinya. Oleh karena itu, para pengemban pelayanan kasih tersebut membutuhkan, di samping dan bersama pendidikan profesional, terutama pembentukan hati. Kedua, tindakan kasih Kristiani harus bebas dari partai dan ideologi. Tindakan tersebut bukan alat perubahan dunia yang dikendalikan secara ideologis dan tidak mengabdi strategi dunia, melainkan sekarang dan di sini merupakan sarana penghadiran kasih, yang selalu dibutuhkan manusia. Ketiga, pelayanan amal kasih yang menjangkau semua lapisan masyarakat. ${ }^{63}$

Kardinal Julius Darmaatmadja dalam kata sambutan penutup Sinode Para Uskup Asia memberikan pernyataan bahwa Gereja hendaknya berpihak terhadap kaum miskin

\footnotetext{
61 F. Hasto Rosariyanto (ed.), Bercermin pada Wajah-wajah Keuskupan Gereja Katolik Indonesia (Yogyakarta: Penerbit Kanisius, 2001), xi.

62 Rosariyanto, Bercermin pada Wajah-wajah Keuskupan, xi.

63 Bdk. Deus Caritas Est, art. 31.
} 
dan tertindas. Keberpihakan Gereja kepada kaum miskin dan tertindas dapat diwujudkan dalam karya pelayanan apapun. Hal ini menuntut bukan semata-mata bekerja bagi mereka, melainkan bekerja sama dan belajar dari mereka tentang apa yang mereka butuhkan dan dambakan, sejauh mereka mampu mengungkapkan, kemudian berjuang agar dambaan-dambaan itu terpenuhi dengan mengubah struktur-struktur dan situasi yang melestarikan kekurangan dan ketidakberdayaan mereka. ${ }^{64}$

Gereja memang harus bersikap terbuka terhadap segala permasalahan yang terjadi, termasuk dalam hal migrasi. Para migran adalah orang-orang miskin yang seringkali mengalami penindasan dan perlakuan yang tidak adil. Gereja tidak perlu menutup diri, tetapi sebaliknya, Gereja mewartakan kasih Allah kepada semua orang karena itu merupakan panggilan Gereja. Kasih Allah melampaui sekat-sekat manusiawi dan berjalan bebas mencari orang-orang lemah, tertindas, dan marjinal dalam masyarakat. ${ }^{65}$ Ecclesia in Asia, art. 34 menegaskan demikian:

Dalam usaha memajukan martabat manusiawi, Gereja menunjukkan sikap mengutamakan cinta kasih akan rakyat miskin serta tak bersuara, sebab Tuhan telah mengidentifikasikan Diri dengan mereka secara istimewa (Mat. 25: 40). Cinta kasih itu tidak mengecualikan siapa pun, tetapi sederhana saja mewujudkan prioritas pelayanan, yang oleh seluruh tradisi Kristiani diwartakan melalui kesaksian. Cinta kasih mengutamakan rakyat miskin itu, serta keputusan-keputusan yang diilhamkan pada diri kami, mau tak mau merangkul

64 Dokumen, FABC 1 (1974), 20.

65 Martin Chen, Teologi Gustavo Gutierrez: Refleksi dari Praksis Kaum Miskin (Yogyakarta: Kanisius, 2006), 123. golongan-golongan tiada taranya, yang terdiri dari rakyat yang lapar, melarat, tunawisma, tanpa reksa pengobatan/perawatan, dan terutama mereka yang sedikit pun tidak mengharapkan masa depan yang lebih baik. Tidak mau mengetahui itu semua kiranya berarti menjadi orang kaya, yang memberi kesan seolah-olah tidak mengenal Lazarus yang terbaring di dekat gerbangnya (Luk 16: 19-31). ${ }^{66}$

Gereja diutus mewujudkan kebaikan, kasih sayang, dan kesembuhan yang dibawa Yesus. ${ }^{67}$ Kesadaran Gereja bahwa ia diutus menjadi saksi Kabar Gembira tentang Kerajaan Allah yang sudah mulai meresapi dunia, mendorongnya untuk melibatkan diri di forum-forum internasional seperti di PBB, maupun di pangung-panggung nasional dan regional untuk mengingatkan terus-menerus perdamaian, berusaha menjadi pengantara dalam sekian konflik yang menghancurkan banyak negara, melawan budaya kematian, mengingatkan masyarakat dunia akan adanya ratusan juta orang yang miskin, teraniaya, yang hidup dalam kesusahan, terus-menerus menyuarakan penolakan kekerasan, menegaskan bahwa hak-hak asasi manusia wajib dihormati tanpa kecuali, menolak perang dan segala kekerasan, aktif melibatkan diri dalam penampungan jutaan pengungsi. ${ }^{68}$ Dengan kata lain, Gereja perlu menjangkau semua orang tanpa pembedaan, sambil berusaha bersama mereka membangun peradaban cinta kasih, didasarkan pada nilai-nilai universal damai, keadilan, solidaritas dan kebebasan, yang menemukan pemenuhan mereka dalam Kristus. ${ }^{69}$

66 Ecclesia in Asia, art. 34.

67 Magnis-Suseno, Katolik Itu Apa?, 189.

68 Magnis-Suseno, Katolik Itu Apa?, 190.

69 Ecclesia in Asia, art. 32. 


\section{KESIMPULAN}

Dalam memperingati Hari Migran dan Pengungsi Sedunia pada tanggal 14 Januari 2018, Paus Fransiskus menegaskan bahwa ia sungguh merasa prihatin terhadap para migran yang melarikan diri dari negara mereka karena perang, penganiayaan, bencana alam, dan kemiskinan. Sejak kunjungannya ke Lampedusa pada tanggal 8 Juli 2013, Paus Fransiskus selalu menempatkan duka para migran dalam hati. Selain itu, Paus Fransiskus kembali mengajak negara-negara untuk peduli terhadap migran, dan terbuka terhadap budaya mereka. ${ }^{70}$ Bagi Paus Fransiskus, para migran bukanlah orang asing, tetapi orang lain (liyan) yang harus diterima dengan segala konsekuensinya.

Paus Fransiskus berpendapat bahwa para migran memiliki martabat sama seperti manusia lainnya. Akan tetapi, nasib mereka seringkali terombang-ambing tidak jelas bahkan ditolak oleh negara-negara karena berbagai alasan. Pada akhirnya, nasib mereka menjadi tidak jelas, yaitu ada yang meninggal di tengah lautan, ada yang dieksploitasi, dan ada yang dijadikan budak.
Keprihatinan tersebut mengusik hati Paus Fransiskus untuk berkali-kali menyerukan bahwa kita semua diajak untuk terlibat dalam memecahkan permasalahan migrasi.

Duka para migran menjadi tanggung jawab bersama. Tentu, dalam hal ini bukan hanya Paus Fransiskus yang terlibat dalam menangani permasalahan ini. Akan tetapi, semua pihak perlu ikut campur tangan dalam mencari solusi terbaik. Paus Fransiskus sungguh memberikan keteladanan bahwa kita semua diajak untuk menerima dengan terbuka kehadiran pada migran. Sumbangan pemikiran Paus Fransiskus memantik kita semua untuk berefleksi tentang siapa sesama kita dan bagaimana kita seharusnya bersikap terhadap sesama manusia. Kita diajak untuk merenungkan kembali Kabar Gembira yang dititipkan Yesus kepada kita, bukan untuk "menyesuaikan diri dengan semangat zaman", melainkan untuk dibebaskan dari kepicikan dan prasangka yang dapat mendistorsikan pengertiannya terhadap Kabar Gembira.

70 Pope Francis, "Message of His Holiness Pope Francis for the 104th World Day of Migran and Refugess 2018", https://w2. vatican.va/content/francesco/en/messages/migration/documents/papa-francesco_20170815_world-migrants-day-2018. html, diakses pada tanggal 15 Maret 2020. 


\section{DAFTAR RUJUKAN}

Allen, John L. The Francis Miracle. New York: Time Book, 2015.

Benediktus XVI. Deus Caritas Est. Jakarta: Departemen Dokumentasi dan Penerangan KWI, 2005.

Bergoglio, Jorge Mario and Abraham Skorka. On Heaven and Earth. United States of America: Large Print, 2013.

Chen, Martin. Teologi Gustavo Gutierrez: Refleksi dari Praksis Kaum Miskin. Yogyakarta: Kanisius, 2006.

Endean, Philip. "Writing on Jesuit Spirituality by Jorge Mario Bergoglio," Studies In the Spirituality of Jesuit, 45/3, Autumn (2013).

Groody, Daniel G. "Crossing the Divide: Foundations of a Theology of Migration and Refugees," Theological Studies Vol. 70 (2009).

Groody, Daniel. "Migrants and Refugees: Christian Faith and the Globalization of Solidarity," International Review of Mission, November (2015).

Fransiskus. Evangelii Gaudium (terj. F.X. Adisusanto dan Bernadeta Harini Tri Prasasti), Bogor: Mardiyuana, 2014.

Hasto Rosariyanto, F. (ed.). Bercermin pada Wajah-wajah Keuskupan Gereja Katolik Indonesia. Yogyakarta: Kanisius, 2001.

Maillard, Sebastian. "Pope Francis, Refugees and Recovering Europe's Soul," The Way, Vol. 55, No. 4, Oktober (2016).
Magnis-Suseno, Franz. Katolik Itu Apa? Sosok, Ajaran, Kesaksian. Yogyakarta: Kanisius, 2017.

Razianto Mada, Kris. "Layanan Optimal untuk Penyumbang Miliaran Dollar AS", Kompas, 24 Maret 2018.

Snyder, Susanna, Joshua Ralston, dan Anges M. Brazal. Church in an Age of Global Migration. Bogor: Mardiyuana, 2016.

Tulud Cruz, Gemma. "Between Identity and Security: Theological Implications of Migration in the Context of Globalization," Theological Studies, Vol. 69 (2008).

Wuar, Yusti H. "Suara Paus bagi Para Migran", Hidup, No. 13, 26 Maret (2017).

Yohanes Paulus II. Ecclesia in Asia, R. Hardawiryana, SJ (terj.), Jakarta: Dokumentasi dan Penerangan KWI, 2000.

\section{Internet :}

Pope Francis, "Message of His Holiness Pope Francis for the 104th World Day of Migran and Refugess 2018", https://w2.vatican.va/ content/francesco/en/messages/migration/ documents/papa-francesco_20170815 world-migrants-day-2018.htm] (diakses tanggal 15 Maret 2020).

Pope Francis, "Message of Hollines Pope Francis for the Celebration of the 51st World Day of Peace", http://w2.vatican.va/content/francesco/en/messages/peace/documents/papa-francesco_20171113_messaggio-51 giornatamondiäle-pace $2018 . \mathrm{html}$ (diakses tanggal 15 Maret 2020). 
